\title{
AUGMENTING EFFECT OF RHEUMATOID SERA IN A STREPTOCOCCAL HAEMAGGLUTINATION TEST*
}

BY

\author{
N. R. LING AND H. J. GIBSON \\ From the Bath Area Clinical Laboratories
}

(RECEIVED FOR PUBLICATION NOVEMBER 1, 1956)

Culture filtrates of streptococci were shown by Rantz, Randall, and Zuckerman (1956) to contain a polysaccharide which attached itself to erythrocytes, preparing them for agglutination by human sera. This polysaccharide was produced by Gram-positive but not by Gram-negative organisms. Its distribution suggested to us a possible relationship to an unidentified antigen responsible for the marked agglutination of streptococci and certain other Grampositive organisms by sera of patients suffering from rheumatoid arthritis (Cecil, Nicholls, and Stainsby, 1930; Dawson, Olmstead, and Boots, 1932). A possible connexion was also suggested by a report that sera from patients suffering from some of the collagen group of diseases showed high titres in the streptococcal haemagglutination test (Rantz, 1953). The titres increased somewhat with age (Rantz, Zuckerman, and Randall, 1952), but apparently bore no relation to previous streptococcal infection (Rantz, Zuckerman, and Randall, 1952; Harris and Harris, 1953). The ease with which this test may be performed made it possible for us to examine sera from a large number of patients of all clinical types. Although higher titres with sera from patients suffering from rheumatoid arthritis were not invariable or specific, a tendency to high titres, which could not be accounted for on an age basis was noted, with occasional unexplained exceptionally high titres accompanied by a strongly positive RoseWaaler test (Rose, Ragan, Pearce, and Lipman, 1948; Waaler, 1940). To account for this phenomenon it was postulated that the high titres obtained with such sera were due to the dual action of an antibody and a co-existing augmenting factor. Evidence in favour of this hypothesis is presented.

* This paper was presented at a clinical meeting of the Heberden Society on December 14, 1956.

\section{Methods and Materials}

Human Erythrocytes of group $\mathrm{O}$ (usually Rh.-negative) were obtained from residues in recently returned bloodtransfusion bottles, and were washed four times with saline before use. Similar titres were recorded in all test systems when the patient's own erythrocytes were employed.

Rose-Waaler Tests were performed with human erythrocytes sensitized with one-quarter of a minimal agglutinating dose ( 1 M.A.D.) of rabbit anti-human immune antibody exactly as previously described (Gibson and Ling, 1956) except that plastic agglutination trays were used. In almost every case the test was also carried out by the sheep cell differential test (Rose, Ragan, Pearce, and Lipman, 1948) and the results agreed with those given by the human cell system.

Human Sera obtained from hospitals in the Bath Area were inactivated at $56^{\circ}$ for 30 minutes before use. They were either fresh or had been stored at $-15^{\circ} \mathrm{C}$.

Streptococcal Filtrates. - Type 12 streptococci, supplied by the Public Health Laboratory, Bath, were grown in tryptose broth at $p \mathrm{H} 7 \cdot 2$ for 4 days as recommended by Rantz, Randall, and Zuckerman (1956). The culture was acidified with a few drops of glacial acetic acid, brought to the boil, and the coarse coagulum of organisms filtered off. The filtrate was stored at $-15^{\circ} \mathrm{C}$. in 50-ml. quantities. For reference purposes, one culture filtrate was dialysed to remove inorganic salts and small organic molecules, taken to dryness under reduced pressure, desiccated, and ground to a fine powder. When reconstituted with saline this preparation was shown to contain all the activity of the original broth.

Polysaccharide-Coated Erythrocytes.-A "saturation dose" of culture filtrate was added to a 10 per cent. suspension of human erythrocytes in $0.15 \mathrm{M}$. $p \mathrm{H} \mathrm{7.0}$ phosphate buffer. After incubation at $37^{\circ} \mathrm{C}$. for 30 minutes the erythrocytes were centrifuged down, washed 
twice with saline, and suspended in saline to an 0.5 per cent. suspension. A "saturation dose" of culture filtrate was one slightly in excess of the minimal amount necessary to produce maximum titre on subsequent addition of the washed suspension to a given serially-diluted nonrheumatoid serum. That this sensitizing effect did not increase with dosage above a certain amount is evident from Fig. 1. Cells coated with cultures from other strains of streptococci and a staphylococcus gave similar titres when tested against human sera in agreement with Rantz, Randall, and Zuckerman (1956). The latter authors have also shown that comparable titres are produced with human, horse, rabbit, and sheep erythrocytes.

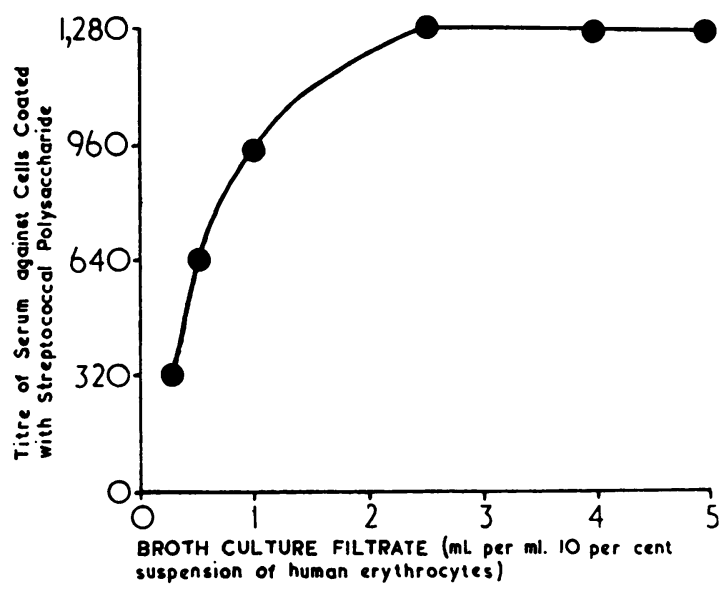

Fig. 1.-Determination of saturation dose of broth culture filtrate for human erythrocytes.

Sensitized Polysaccharide-coated Erythrocytes.-Human sera were titrated against polysaccharide-coated cells. One-eighth of a minimal agglutinating dose of serum was added directly to an 0.5 per cent. saline suspension of coated cells and mixed with it. Sensitized suspensions were allowed to stand at least 30 minutes before use. As $4^{\circ} \mathrm{C}$. was shown to be more effective than $37^{\circ} \mathrm{C}$. for the sensitization, the suspensions were stored in the refrigerator when not in use. All cell suspensions were prepared on the same day as they were used. On the single occasion when a sensitized cell suspension was tested after storage overnight at $4^{\circ} \mathrm{C}$., however, the titration was unaffected.

Titrations of human sera against sensitized and nonsensitized polysaccharide-coated cells were performed in Perspex agglutinating trays (M.R.C. pattern). Doubling dilutions in $0.25 \mathrm{ml}$. volumes of saline were made and an equal volume of cell suspension was added. The completed trays were allowed to stand several hours at room temperature and were stored overnight at $4^{\circ} \mathrm{C}$. Coarse agglutination was produced on agitation of the trays. Slightly higher titres were obtained when readings were taken directly by the "settled pattern" technique. More than usual care in the cleaning of the trays was necessary in order to obtain a clear endpoint when sensitized cells were used. Reciprocals of titres obtained by the latter method of reading are those recorded in Tables I-VI and Figs 1 and 2. Control suspensions of uncoated erythrocytes were also used.

\section{Experiments and Results}

All sera were tested initially by the Rose-Waaler technique and against polysaccharide-coated cells. Sera were then diluted 1 in 5 with saline and absorbed for one hour at room temperature with a volume of packed polysaccharide-coated erythrocytes equivalent to a ratio of coated cells: serum twice that present at the end-titre of the titration against the coated cells. For example, if the end-titre were 1 in 500 , absorption of $1 \mathrm{ml}$. of 1 in 5 serum would be carried out with $0.5 \mathrm{ml}$. packed, coated erythrocytes. The suspension was then centrifuged, and the supernatant tested against:

(a) Unsensitized Coated Cells.-All absorbed sera were negative to this test.

(b) Sensitized Coated Cells.-The titre obtained depended on two factors:

(i) the serum under test

(ii) the serum employed for the sensitization.

Comparison of Activity of Sera in the Rose-Waaler Test with Activity of Sera against Sensitized Polysaccharide-coated Cells.-All sera which werê strongly positive by the Rose-Waaler test showed very high titre (between 5,000 and 600,000) agains 5 sensitized coated cells even when a low titre agains unsensitized coated cells had been recorded. For those definitely negative to the Rose-Waaler test, on the other hand, low titres (up to 100) were recorded, and there was a marked but not quite arithmetical relationship between the activity in the two systems with all batches of sera tested. This is evident from Table I (opposite). A similar Table comparing the titres in the Rose-Waaler test with those against unsensitized coated cells is given for comparison (Table II, opposite). The titres of the augmented reaction were on average much higher than in the Rose-Waaler test.

Sensitizing Quality of Human Sera.-By no means all sera were suitable sensitizers for the detection of the augmenting factor. In our short series of normal and pathological sera, some 18 per cent. showed good sensitizing activity. The suitability bore no relation to the titre against coated cells or to the age of the patient. Sera from patients with jaundice (other than obstructive jaundice) were a reliable source of good sensitizers. Of six tested, four were active, three markedly so. The titres against coated cells were not exceptional in any way, viz. 160, 160, $80,80,320,80$. A large volume of blood was drawn from one of these patients and the serum stored in 
TABLE I

COMPARISON OF ROSE-WAALER TITRE (HUMAN SYSTEM) WITH TITRE AGAINST SENSITIZED POLYSACCHARIDE-COATED HUMAN ERYTHROCYTES

\begin{tabular}{|c|c|c|c|c|c|c|c|c|c|c|c|}
\hline \multirow{3}{*}{$\begin{array}{c}\text { Rose- } \\
\text { Waaler } \\
\text { Titre }\end{array}$} & \multirow{3}{*}{$\begin{array}{c}\text { Number } \\
\text { of } \\
\text { Sera }\end{array}$} & \multicolumn{10}{|c|}{$\begin{array}{c}\text { Titre against Cells coated with Streptococcal Polysaccharide and Sensitized with a } \\
\text { Human Serum ( } \frac{1}{8} \text { M.A.D.) }\end{array}$} \\
\hline & & \multicolumn{2}{|c|}{$>20,000$} & \multicolumn{2}{|c|}{$5,000-20,000$} & \multicolumn{2}{|c|}{$1,000-5,000$} & \multicolumn{2}{|c|}{$100-1,000$} & \multicolumn{2}{|c|}{$<100$} \\
\hline & & No. & $\begin{array}{l}\text { Per cent. } \\
\text { of Group }\end{array}$ & No. & $\begin{array}{l}\text { Per cent. } \\
\text { of Group }\end{array}$ & No. & $\begin{array}{l}\text { Per cent. } \\
\text { of Gi oup }\end{array}$ & No. & $\begin{array}{l}\text { Per cent. } \\
\text { of Group }\end{array}$ & No. & $\begin{array}{l}\text { Per cent. } \\
\text { of Group }\end{array}$ \\
\hline$>500$ & 21 & 12 & 57 & 8 & 38 & 1 & 5 & 0 & 0 & 0 & 0 \\
\hline $200-500$ & 9 & 3 & 33 & 5 & 56 & 0 & 0 & 1 & 11 & 0 & 0 \\
\hline $50-200$ & 11 & 0 & 0 & 4 & 36 & 4 & 36 & 2 & 18 & 1 & 9 \\
\hline $10-50$ & 20 & 0 & 0 & 0 & 0 & 5 & 25 & 11 & 55 & 4 & 20 \\
\hline$<10$ & 51 & 0 & 0 & 0 & 0 & 0 & 0 & 2 & 4 & 49 & 96 \\
\hline
\end{tabular}

TABLE II

COMPARISON OF ROSE-WAALER (HUMAN SYSTEM) WITH TITRE AGAINST UNSENSITIZED POLYSACCHARIDE-COATED CELLS

\begin{tabular}{|c|c|c|c|c|c|c|c|c|c|}
\hline \multirow{3}{*}{$\begin{array}{l}\text { Rose- } \\
\text { Waaler } \\
\text { Titre }\end{array}$} & \multirow{3}{*}{$\begin{array}{c}\text { Number } \\
\text { of } \\
\text { Sera }\end{array}$} & & & \multicolumn{6}{|c|}{ Titre against Cells Coated with Streptococcal Polysaccharide } \\
\hline & & \multicolumn{2}{|c|}{$>1000$} & \multicolumn{2}{|c|}{$400-1000$} & \multicolumn{2}{|c|}{$100-400$} & \multicolumn{2}{|c|}{$<100$} \\
\hline & & No. & $\begin{array}{l}\text { Per cent. } \\
\text { of Group }\end{array}$ & No. & $\begin{array}{l}\text { Per cent. } \\
\text { of Group }\end{array}$ & No. & $\begin{array}{l}\text { Per cent. } \\
\text { of Group }\end{array}$ & No. & $\begin{array}{l}\text { Per cent. } \\
\text { of Group }\end{array}$ \\
\hline$>500$ & 20 & 8 & 40 & 3 & 15 & 8 & 40 & 1 & 5 \\
\hline $200-500$ & 14 & 2 & 14 & 3 & 21 & 5 & 36 & 4 & 29 \\
\hline $50-200$ & 19 & 6 & 31 & 2 & 10 & 6 & 31 & 5 & 26 \\
\hline $10-50$ & 27 & 3 & 11 & 6 & 22 & 9 & 33 & 9 & 33 \\
\hline$<10$ & 99 & 8 & 8 & 15 & 15 & 37 & 37 & 39 & 39 \\
\hline
\end{tabular}

$0.5 \mathrm{ml}$. volumes at $-15^{\circ} \mathrm{C}$. It was thus possible to use the same sensitizer for the whole series of measurements of augmenting factor. In general, similar changes in titre were brought about in each of a given battery of test augmenting sera by a change of sensitizer. Four out of five sera from cases of obstructive jaundice failed to sensitize. The relative frequency of the occurrence of the sensitizing antibody in sera from jaundiced patients recalls that jaundice has been reported to induce a remission of rheumatoid arthritis in some cases (Hench, 1935), while occasional positive Rose-Waaler tests with sera from patients with hepatitis have also been reported (Wager, 1950).

Table III shows the sensitizing quality of sera tested. As the sensitizing dose is based on the titre against unsensitized coated cells and it is postulated that the antibody contribution to this titre is small in sera containing large amounts of augmenting factor, such sera would be expected to be poor sensitizers. This was so. Many sera agglutinated coated red cells to a significant titre and yet showed neither
TABLE III

ANALYSIS OF SENSITIZING SERA TESTED

\begin{tabular}{c|c|c|c}
\hline $\begin{array}{c}\text { Sensitizi- } \\
\text { ing } \\
\text { Action }\end{array}$ & $\begin{array}{c}\text { Total } \\
\text { Number } \\
\text { of Sera }\end{array}$ & $\begin{array}{c}\text { Mean } \\
\text { Titre } \\
\text { against } \\
\text { Coated } \\
\text { Cells }\end{array}$ & Clinical Conditions Include: \\
\hline $\begin{array}{c}\text { Very } \\
\text { good }\end{array}$ & 9 & $\begin{array}{l}\text { Jaundice other than obstructive (4) } \\
\text { Acute rheumatism (1) } \\
\text { Iron deficiency anaemia (1) } \\
\text { Osteogenic sarcoma (1) } \\
\text { Senile osteoporosis (1) }\end{array}$ \\
\hline Fair & 8 & 155 & $\begin{array}{l}\text { Jaundice other than obstructive (2) } \\
\text { Obstructive jaundice (1) } \\
\text { Vena caval thrombosis (1) }\end{array}$ \\
\hline Poor & 7 & $\begin{array}{l}\text { Haemolytic anaemia (1) } \\
\text { Gout (1) } \\
\text { Rheumatoid arthritis (1) }\end{array}$ \\
\hline $\begin{array}{l}\text { Very } \\
\text { poor }\end{array}$ & 33 & $\begin{array}{l}\text { Rheumatoid arthritis (12) } \\
\text { Acute rheumatism (1) } \\
\text { Obstructive jaundice (4) } \\
\text { Rheumatic heart disease (1) } \\
\text { Syphilis (1) } \\
\text { Nephritis (1) } \\
\text { Myeloma (1) } \\
\text { Megaloblastic anaemia (1) }\end{array}$ \\
\hline
\end{tabular}


TABLE IV

EFFECT OF WASHING AFTER SENSITIZATION OF POLYSACCHARIDE-COATED ERYTHROCYTES

\begin{tabular}{|c|c|c|c|c|c|c|c|c|c|c|c|c|}
\hline \multirow{2}{*}{$\begin{array}{l}\text { Augmenting } \\
\text { Serum }\end{array}$} & \multirow{2}{*}{$\begin{array}{c}\text { Sensitizing } \\
\text { Serum }\end{array}$} & \multirow{2}{*}{$\begin{array}{c}\text { Treatment } \\
\text { of Sensitized } \\
\text { Cells }\end{array}$} & \multicolumn{10}{|c|}{ Dilution of Augmenting Serum } \\
\hline & & & 100 & 200 & 400 & 800 & 1,600 & 3,200 & 6,400 & 12,800 & 25,600 & 51,200 \\
\hline \multirow{2}{*}{$\begin{array}{l}\text { Case of } \\
\text { Rheumatoid } \\
\text { Arthritis (1) }\end{array}$} & \multirow{2}{*}{$\begin{array}{l}\text { Acute } \\
\text { Rheumatic } \\
\text { Fever }\end{array}$} & unwashed & ++ & ++ & ++ & + & \pm & - & - & - & 一 & 一 \\
\hline & & washed & ++ & ++ & + & \pm & - & - & - & - & - & - \\
\hline \multirow{2}{*}{$\begin{array}{l}\text { Case of } \\
\text { Rheumatoid } \\
\text { Arthritis (2) }\end{array}$} & \multirow[b]{2}{*}{ Jaundice } & unwashed & ++ & ++ & ++ & ++ & ++ & ++ & ++ & + & \pm & - \\
\hline & & washed & ++ & ++ & ++ & ++ & ++ & ++ & ++ & + & \pm & - \\
\hline
\end{tabular}

Sera (1) and (2) were from patients suffering from rheumatoid arthritis and were absorbed against coated cells before testing.

augmenting nor sensitizing properties, suggesting that more than one type of antibody against this antigen may be present in human serum. The titres against coated cells of some other active sensitizing sera from a variety of patients were:

$\begin{array}{lllr}\text { Osteogenic sarcoma } & \ldots & \ldots & 80 \\ \text { Acute rheumatism } & . & \ldots & 640 \\ \text { Senile osteoporosis } & . & \ldots & 80 \\ \text { Iron deficiency anaemia } & \ldots & 640\end{array}$

Nature of the Reaction.-That in certain of its properties, the Rose-Waaler factor resembles an enzyme has been previously remarked upon (Gibson and Ling, 1956; Svartz, 1956). A number of experiments were devised to test whether this also applied to the streptococcal augmenting factor, or whether some other mechanism, such as a Coombs-like reaction with adsorbed $\gamma$-globulin, was operating.

(1) Effect of Washing after Sensitization.-A portion of the sensitized polysaccharide-coated cells was centrifuged, washed once with saline, and resuspended. A suitable augmenting serum was titrated against washed and unwashed cells. The titre was unchanged or dropped slightly (Table IV). If the augmenting factor reacted in antibody-like fashion with human $\gamma$-globulins other than the attached sensitizing antibody, removal of the competing substances should have raised the titre.

(2) Mixing of Sensitizing and Augmenting Sera.A serum which had been previously shown to be rich in sensitizing antibody was mixed with an equal volume of a serum known to contain large amounts of augmenting factor for this test. No matter how long they were allowed to stand, the titre of the combined sera was always greater than the mean (Table V). It was concluded from this and an experiment to be described later that no demonstrable interaction of the two factors takes place in the absence of antigen.

(3) Variation of Activity with pH.-In the case of the Rose-Waaler reaction, clear evidence of a $p H$ optimum at approximately $p \mathrm{H} 7 \cdot 5$ was obtained
TABLE V

EFFECT OF MIXING A SENSITIZING AND AN AUGMENTING SERUM

\begin{tabular}{|c|c|c|c|}
\hline Patient & $\begin{array}{l}\text { Sensitizing } \\
\text { Quality of } \\
\text { Serum }\end{array}$ & $\begin{array}{l}\text { Augmenting } \\
\text { Quality of } \\
\text { Serum }\end{array}$ & $\begin{array}{l}\text { End-Titre } \\
\text { against Cells } \\
\text { Coated with } \\
\text { Streptococcal } \\
\text { Polysaccharide }\end{array}$ \\
\hline $\begin{array}{l}\text { (1) Case of Simple } \\
\text { Ganglia of } \\
\text { Wrist Joint }\end{array}$ & Very good & Very poor & 1,280 \\
\hline $\begin{array}{l}\text { (2) Case of } \\
\text { Rheumatoid } \\
\text { Arthritis }\end{array}$ & Very poor & Very good & 80 \\
\hline $\begin{array}{l}\frac{1}{2}(1)+\frac{1}{2}(2) \\
\left(1 \mathrm{hr} \text { at } 25^{\circ} \mathrm{C} .\right)\end{array}$ & - & 一 & $>10,240$ \\
\hline $\begin{array}{l}\frac{1}{2}(1)+\frac{1}{2}(2) \\
\left(18 \mathrm{hrs} \text { at } 4^{\circ} \mathrm{C} .\right)\end{array}$ & - & - & $>10,240$ \\
\hline
\end{tabular}

when the saline diluent was replaced by $0 \cdot 15 \mathrm{M}$ phosphate buffers (Fig. 2,a). A similar result was obtained with the euglobulin fraction. The simple agglutination of human cells by rabbit antihuman haemolysin, on the other hand, showed (Fig. 2,b) the expected slight increase of titre as the $p \mathrm{H}$ was dropped from 8 to 6 (Abraham, 1954). The direct titration of a non-augmenting serum against unsensitized coated cells appeared to be unaffected by $p \mathrm{H}$ in this range (Fig. 2,c), but a sharp falling off in activity of the augmenting factor for sensitized coated cells below $p \mathrm{H} 7$ could also be demonstrated in this system (Fig. 2,d). These experiments, taken in conjunction with the known difficulty of absorbing out the Rose-Waaler factor with its substrate, tended to support the idea that the active substance resembled an enzyme in many of its properties. But the resemblance could not be extended to the time relationship of the reaction. Although the initial velocity was linear with respect to time, the RoseWaaler reaction of rheumatoid serum with human cells sensitized with rabbit antihuman erythrocyte antibody appeared to be complete in 20 minutes at $37^{\circ} \mathrm{C}$. and in 80 minutes at $4^{\circ} \mathrm{C}$. 
(a) Rose-Waaler titration (human system)

(b) Rabbit anti-human haemolysin versus human erythrocytes

- - - (c) Human sensitizing serum versus human erythrocytes coated with streptococcal polysaccharide

- - (d) Absorbed rheumatoid serum versus sensitized polysaccharide-coated erythrocytes

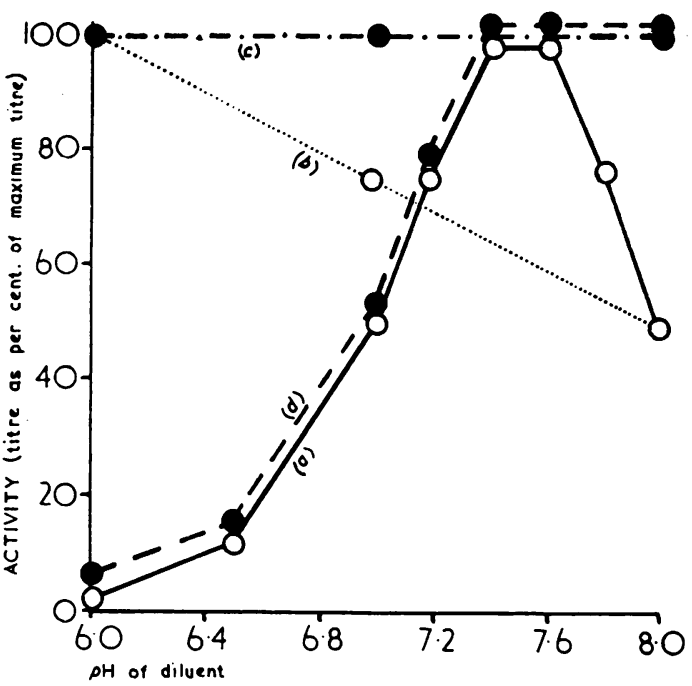

Fig. 2.-Effect of $p H$ variation on sensitizing and augmenting reactions.

(4) Co-existence of Sensitizer and Augmenter.Since the hypothesis requires that good augmenting sera showing a high titre against unsensitized polysaccharide-coated cells should contain small amounts of sensitizing antibody, attempts were made, which were successful, to demonstrate an augmentation effect of such a serum with polysaccharide coated cells which had been sensitized with the same serum. In the example shown (Table VI), a quantity equivalent to ten times the original agglutinating dose of a rheumatoid serum was added directly to an ice-cold
0.5 per cent. suspension of coated cells in $0.15 \mathrm{M}$ $p \mathrm{H} 6$ phosphate buffer, and was mixed with it by inverting the tube twenty times. The cells were centrifuged down, the supernatant discarded, and the cells washed three times with ice-cold $p \mathrm{H} 6$ buffer, and finally resuspended in $0.15 \mathrm{M} p \mathrm{H} 7$ buffersaline. The washing operations were performed as quickly as possible. The suspension prepared was tested against another sample of the same rheumatoid serum which had been separately absorbed against coated cells and a control (non-augmenting) serum similarly treated. A clear difference was obtained, indicating that a true sensitization had taken place.

\section{Discussion}

Human sera may contain an antibody against a polysaccharide produced by Gram-positive organisms, or an augmenting factor for this reaction, or both antibody and augmenter. Acceptance of the evidence that the two factors may co-exist and do not interact in the absence of the antigen would provide, for the first time, a possible in vivo function of an augmenting factor present in large amounts in the sera of many patients with rheumatoid arthritis and in small amounts in the sera of some other patients. The hypothesis resembles, in some ways, that put forward by Wager (1950) to account for the high titres frequently obtained with rheumatoid sera in a streptococcal agglutination test. Lamont-Havers (1955) separated activating and agglutinating components by a method of water precipitation for the agglutinating of Group A haemolytic streptococci by rheumatoid sera. He showed that the activating factor was present in the precipitate and that the agglutination factor present in the supernatant could be replaced by a similar factor found in normal human serum. A comprehensive theory at the present time, however, would need to account for agglutination produced by rheumatoid sera with Brucella abortus suspensions sensitized with certain

TABLE VI

USE OF THE SAME PATIENT'S SERUM FOR SENSITIZATION AND AUGMENTATION

\begin{tabular}{|c|c|c|c|c|c|c|c|c|c|c|c|}
\hline \multirow{2}{*}{ Patient } & \multirow{2}{*}{$\begin{array}{l}\text { Augmenting } \\
\text { Quality of } \\
\text { Patient's } \\
\text { Serum }\end{array}$} & \multirow{2}{*}{$\begin{array}{l}\text { Sensitizing } \\
\text { Serum }\end{array}$} & \multicolumn{9}{|c|}{ Dilution of Patient's Serum } \\
\hline & & & 10 & 20 & 40 & 80 & 160 & 320 & 640 & 1,280 & 2,560 \\
\hline $\begin{array}{l}\text { (1) Case of } \\
\text { Rheumatoid } \\
\text { Arthritis }\end{array}$ & Very good & None & - & - & - & - & - & - & - & - & - \\
\hline (1) & Very good & (1) & ++ & ++ & ++ & ++ & ++ & ++ & ++ & \pm & - \\
\hline $\begin{array}{l}\text { (2) Non- } \\
\text { Rheumatoid }\end{array}$ & Very poor & (1) & - & - & - & - & - & - & - & - & - \\
\hline
\end{tabular}

The polysaccharide-coated group-O human erythrocytes were sensitized with serum from a rheumatoid arthritis patient (1) and the suspension tested against absorbed serum from the same patient and from a non-rheumatoid patient (2). 
human sera (Foz and Batalla, 1955), and for a reaction with Bact. pneumoniae polysaccharide and blood group A polysaccharide attached to sheep cells and sensitized with the appropriate rabbit immune antibody (Greenbury, 1956). It would need also to account for an antibody-like reaction with normal human $\gamma$-globulin, either directly as a precipitin reaction (Epstein, Johnson, and Ragan, 1956) or when tanned on to sheep cells (Heller, Jacobson, Kolodny, and Kammerer, 1954; Jacobson, Kammerer, Wolf, Epstein, and Heller, 1956), or with a particular portion or kind of human $\gamma$-globulin (Williams, Stone, Jenkins, Evans, and Bunim, 1956; Waller and Vaughan, 1956). Some of these effects are weak or difficult to reproduce. In addition, the now well-established reaction of the Rose-Waaler factor with mammalian red cells sensitized with immune haemolysins has been shown to have its own peculiarities of specificity as between animal species and types of sensitizers (Jochem, Eyquem, and Jacqueline, 1955; Dickgiesser and Harter, 1953). Waller and Vaughan (1956) have shown that a low proportion of human sera of very high Rhesus antibody titre can be used as sensitizers for $R h$.positive cells; the sensitizing capacity was not correlated with agglutination end-titre. Without exception the activities of human sera in the various systems have been reported to be positive with sera showing a positive Rose-Waaler test and negative with sera showing a negative Rose-Waaler test. A most attractive explanation of the reported phenomena would, therefore, appear to be the simplest, namely, that in all cases the same Rose-Waaler factor is involved. Direct evidence on this point has sometimes been obtained by the various authors. But there are a number of obstacles to outright acceptance of this convenient solution. Our own results, for instance, give no indication of a direct interaction between the agglutination augmentation factor and human $\gamma$-globulin or even a small portion of human $\gamma$-globulin until the configuration is altered by attachment to a suitable antigen. In the traditional test also, an action with the haemolysin in the absence of erythrocyte has never been reported (noted by Jochem, Eyquem, and Jacqueline, 1955). In our own experiments with coated erythrocytes, as in those of Greenbury (1956), it is not absolutely certain that the erythrocyte is merely a vehicle or indicator and not a participant in the reaction. Absence of activity in systems containing $\gamma$-globulin even when attached to an antigenic surface has also been reported. Failure to obtain activity with human Rh.-positive cells saturated with low titre incomplete Rhesus antibody (Waller and Vaughan, 1956) confirms our own experience. A theory that the Rose-Waaler factor reacted with the incomplete antibody portion of sensitizers (Dickgiesser and Harter, 1953) does not appear to have general applicability (Greenbury, 1956). Negative results with experimental systems are indeed more common than one would be led to believe by the wealth of reports of positive effects. Human A cells sensitized with natural human anti-A, and sheep cells sensitized with sera giving a positive Paul Bunnell test are examples of negative substrates.

The alternative explanation, that different but related factors are involved in each reported reaction, presents a different kind of difficulty. Although it is not unlikely that other agglutination reactions, thought to be due entirely to adherent antibody, are in reality made up of the dual action of antibody and an augmenting factor, it does not seem probable that the level of different augmenters in human sera would all change in the same direction at the same time.

It is an open question at the present time whether rheumatoid sera contain a single Rose-Waaler factor or whether a number of globulins of similar properties are similarly distributed. In either case this field will continue to be of importance in the study of the collagen group of diseases.

The reaction described employs human erythrocytes and sensitizing and augmenting factors present in human serum. The only non-human material in the reaction is streptococcal carbohydrate. Up to the present the theory of a hypersensitivity mechanism underlying the pathogenesis of the collagen diseases has lacked the support which demonstration of a relevant antibody would give. By the mechanism here proposed an antibody might be present in trace amounts, but in association with an augmenter its effects could be increased to give a significant level of activity.

\section{Summary}

(1) When human Group-O erthrocytes, treated with the products of growth of Gram-positive organisms, are sensitized with an antibody-like principle present in approximately 18 per cent. of normal and pathological human sera, they are agglutinated by sera from cases of rheumatoid arthritis in a way which closely parallels the RoseWaaler activity of the same sera.

(2) The titre of human sera against erythrocytes coated with the polysaccharide produced by Grampositive organisms is a measure, not of antibody alone, but of antibody plus augmenting factor.

(3) It can be shown that the augmenting factor and sensitizing antibody may coexist in the same serum and react with human Group-O Rh.-negative cells 
coated with polysaccharide from Gram-positive cocci.

(4) Some properties of the agglutinin augmenting factor are described and the significance of the results discussed.

We wish to express our thanks to Dr. Paul G. Mann of the Public Health Laboratory Service, Bath, for much help and advice.

\section{REFERENCES}

Abraham, E. P. (1954). In "Lectures on General Pathology", ed. H. Florey. Lloyd-Luke, London.

Cecil, R. L., Nicholls, E. E., and Stainsby, W. J. (1930). Amer. J. Path,, 6, 619.

Dawson, M.'H., Olmstead, M., and Boots, R. H. (1932). J. Immunol., $23,187$.

Dickgiesser, F., and Harter, F. (1953). Z. ges. exp. Med., 122, 221.

Epstein, W., Johnson, A., and Ragan, C. (1956). Proc. Soc. exp. Biol." (N.Y.), 91, 235 .

Foz, A., and Batalla, E. (1955). Rev. esp. Reum., 6, 142 (Abs. in Annals of the Rheumatic Diseases (1956), 15, 206).

Gibson, H. J., and Ling, N. R. (1956). Annals of the Rheumatic Diseases, 15, 246.

Greenbury, C. L. (1956). Lancet, 2, 644.

Harris, T. N., and Harris, S. (1953). J. Bact., 66, 159.

Heller, G. Jacobson, A. S., Kolodny, M. H., and Kammerer, W. H. (1954). J. Immunol., 72, 66.

Hench, P. S. (1935). Med. Clin. N. Amer., 19, 551.

Jacobson, A. S., Kammerer, W. H., Wolf, J., Epstein, W. V., and Heller, G. (1956). Amer. J. Med., 20, 490.

Jochem, E., Eyquem, A., and Jacqueline, F. (1955). Ann. Inst. Pasteur, 88, 625 .

Lamont-Havers, R. W. (1955). Proc. Soc. exp. Biol. (N.Y.), 88, 35.

Rantz, L. A. (1953). J. clin. Invest., 32, 596.

-, Randail, E., and Zuckerman, A. (1956). J. infect. Dis., 98, 211. Zuckerman, A., and Randall, E. (1952). J. Lab. clin. Med., 39, 443.

Rose, H. M., Ragan, C., Pearce, E., and Lipman, M. O. (1948). Proc. Soc. exp. Biol. (N.Y.), 68, 1 .

Svartz, N. (1956). Lancet, $2,194$.

Wager, O. (1950). Ann. Med. exp. Biol. Fenn., 28, Suppl. 8.

Waaler, E. (1940). Acta path. microbiol. scand., 17, 172.

Waller, M. V., and Vaughan, J. H. (1956). Proc. Soc. exp. Biol. (N.Y.), $92,198$.

Williams, R. R., Stone, S. S., Jenkins, J., Evans, R. L., and Bunim, J. J. (1956). Annals of the Rheumatic Diseases, 15, 76.

Effet accroissant des sérums rhumatismaux dans une réaction d'hémagglutination streptococcique

RÉSUMÉ

(1) Quand des érythrocytes du groupe humain " $O$ ", traités aves les produits de croissance d'organismes
Gram-positifs, sont sensibilisés avec un principe de nature anticorps, présent dans environ $18 \%$ de sérums humains normaux et pathologiques, ils sont agglutinés par les sérums provenant de cas d'arthrite rhumatismale, d'une facon qui suit de très prés l'activité Rose-Waaler des mêmes sérums.

(2) Le titre de sérums humains contre des érythrocytes enduits du polysaccharide produit par des organismes Gram-positifs est une mesure, non pas de l'anticorps seul, mais de l'anticorps plus un facteur accroissant.

(3) On peut démontrer que le facteur accroissant et l'anticorps sensibilisateur peuvent coexister dans le même sérum et réagir avec les globules $R h$-négatives du groupe humain " $O$ ". enduites de polysaccharides provenant de cocci Gram-positifs.

(4) On décrit quelques propriétés du facteur accroissant de l'agglutinine et on discute la signification des résultats.

\section{Efecto acrecentante de los sueros reumáticos en una reacción de hemaglutinación estreptococcica}

\section{Sumario}

(1) Cuando se sensibilizan los enritrocitos del grupo humano "O", tratados con los productos de crecimiento de organismos Gram-positivos, con un principio de naturaleza de anticuerpo, presente en cerca de un $18 \%$ de los sueros humanos normales y patológicos, éstos se ven aglutinados por sueros procedentes de casos de artritis reumatoide de una manera muy parecida a la actividad Rose Waaler de los mismos sueros.

(2) El titre de sueros humanos contra eritrocitos cubiertos de polisacarido producido por organismos Gram-positivos ofrece una medida no del anticuerpo solo sino del anticuerpo más un factor acrecentante.

(3) Se puede comprobar que el factor acrecentante y el anticuerpo sensibilizador pueden coexistir en el mismo suero y reaccionar con los glóbulos Rh-negativos del grupo humano " $O$ " cubiertos de polisacarido procedente de cocos Gram-positivos.

(4) Se describen algunas propiedades del factor acrecentante de la aglutinina y se discute el significado de los resultados. 